\title{
The impact of organisational culture and person-organisation fit on job satisfaction and organisational commitment in China and the USA
}

\section{Charlotte Shelton}

1901 NW Blue Parkway,

Unity Village, MO 64065-0001, USA

E-mail: sheltoncd@att.net

\section{Myles Gartland*}

Helzberg School of Management, Rockhurst University, 1100 Rockhurst Road, Kansas City, MO 64110-2561, USA and

Faculty of Management and Economics, Gdansk University of Technology, Narutowicza 11/12 80-233, Gdańsk, Poland E-mail: myles.gartland@rockhurst.edu

*Corresponding author

\section{Martin Stack}

Helzberg School of Management, Rockhurst University, 1100 Rockhurst Road, Kansas City, MO 64110-2561, USA E-mail: Martin.Stack@rockhurst.edu

\begin{abstract}
This study investigated the impact of organisational culture and person-organisation fit on job satisfaction and organisational commitment using data collected from 1,838 employees in 129 US and 111 Chinese firms. We hypothesised that:

1 there is a significant relationship between perceived organisational culture and work attitudes

2 there is a significant gap between practices (perceived culture) and values (preferred culture)

3 job satisfaction and commitment are inversely related to the size of the perceived/preferred gap (P-O fit)

$4 \mathrm{P}-\mathrm{O}$ fit is a stronger predictor of job satisfaction and organisational commitment than country

5 perceived culture is a stronger predictor of job satisfaction and organisational commitment than either country or P-O fit.

Three of these five hypotheses were fully supported, two were partially supported; however little evidence was found to support the value of P-O fit as a strong predictor of work attitudes. The theoretical and practical implications of these findings are discussed.
\end{abstract}

Keywords: commitment; job satisfaction; organisational culture; organisational culture inventory; person-organisation fit; P-O fit; work attitudes; China; USA. 
Reference to this paper should be made as follows: Shelton, C., Gartland, M. and Stack, M. (2011) 'The impact of organisational culture and person-organisation fit on job satisfaction and organisational commitment in China and the USA', Int. J. Management Development, Vol. 1, No. 1, pp.15-39.

Biographical notes: Charlotte Shelton is the President and CEO of Unity. She has owned her own international consulting business and served as the Chair of the Management, Marketing and MIS Division at Rockhurst University. Her other books are Quantum Leaps: 7 Skills for Workplace ReCreation and The NeXt Revolution: What Gen X Women Want at Work and How their Boomer Bosses can Help them Get it.

Myles Gartland is an Associate Professor at the Helzberg School of Management, Rockhurst University and a Visiting Professor at the Faculty of Management and Economics, Gdansk University of Technology in Poland. His research and teaching are in the areas of competitive analysis and strategy formulation as well as issues related to globalisation. He is interested in issues such as industry evolution, evolutionary economics and boundaries of the firm; with specific interest in the healthcare industry. He has published in numerous management and economics journals.

Martin Stack is a Professor of Management and International Business at the Helzberg School of Business, Rockhurst University. He has co-authored several book chapters and had articles published in a number of journals including Business History Review, Business Horizons, Journal of Macromarketing, Journal of Management History and Journal of Economic Issues. He works primarily in the areas of business strategy and international business and he is currently working on a book regarding the internationalisation of healthcare. He is also working on several essays regarding how the brewing industry is globalising.

\section{Introduction}

In an era of declining employment security, employee job satisfaction and commitment are at risk. Numerous studies suggest a trend towards decreased employee loyalty and increased voluntary turnover (Zuboff, 2004). Yet, simultaneously organisations are faced with pending employment shortages driven by aging workers and an under-skilled workforce (Kaihla, 2003). Developing the social capital necessary for success in a highly competitive global environment has become a key management challenge. Understanding the relationships among job satisfaction, commitment and organisational culture and how these relationships vary across national cultures is fundamental to meeting the human resource challenges of multinational corporations.

The purpose of this study was to investigate the impact of organisational culture and person-organisation fit (P-O fit) on both job satisfaction and organisational commitment in two countries, USA and China with historically different national values (Hofstede, 1980; Hofstede and Peterson, 2000). Tett and Meyer (1993, p.261) define job satisfaction as the "affective attachment to the job viewed either in its entirety (global satisfaction) or with regard to particular aspects (facet satisfaction; e.g., supervision)". Organisational commitment, on the other hand, is a measure of "the strength of an individual's 
identification with and involvement in a particular organization" [Porter et al., (1974), p.604]. Thus, job satisfaction is reflected in the feelings that an employee has regarding his/her job while organisational commitment represents the degree to which an employee identifies with the goals and values of an organisation and, thus, desires to maintain membership therein.

Both of these work attitudes are of critical importance because both are related to a variety of behavioural outcomes. For example, job satisfaction is a key variable in almost all turnover theories (Dickter et al., 1996; Lee et al., 1999). Employees who are more satisfied with their jobs are less likely to resign (Carsten and Spector, 1987; Cotton and Tuttle, 1986; Mobley et al., 1979; O'Reilly et al., 1991; Tett and Meyer, 1993); they have reduced absenteeism (Gellatly, 1995; Hackett and Guion, 1985); and they are more likely to demonstrate organisational citizenship behaviour (Organ and Konovsky, 1989). Also numerous studies have found positive relationships among employee job satisfaction, customer satisfaction, organisational productivity and profitability (Burke, 1995; Hallowell et al., 1996; Schmit and Allscheid, 1995).

Organisational commitment has an equally compelling body of literature. Studies suggest that an employee's level of organisational commitment is an even stronger predictor of turnover than job satisfaction (Mowday et al., 1982). Employees who are highly committed to their organisations are less likely to hold an intention to leave (Mathieu and Zajac, 1990; McDonald, 1993; Meyer et al., 1993; O'Reilly and Chatman, 1986) or to actually leave their jobs (Netemeyer et al., 1995; Whitener and Walz, 1993). Highly committed employees are also more likely to perform well (Angle and Perry, 1981; Mathieu and Zajac, 1990; Meyer et al., 1989) and less likely to experience stress (Begley and Czajka, 1993). Such employees also express more positive affect and loyalty (O'Reilly and Caldwell, 1980) and act more pro-socially (O'Reilly and Chatman, 1986; Organ, 1988). Internationally, commitment is correlated with higher organisational citizenship behaviour in Israel (Koslowsky et al., 1988) and New Zealand (Inkson, 1977); and it is related to lower intent to leave in India (Agarwal, 1993) and Japan (Marsh and Mannari, 1977).

Several studies have identified differences in levels of job satisfaction and commitment across cultures (Clugston et al., 2000; Kanungo and Wright, 1983; Lincoln and Kalleberg, 1985; Luthans et al., 1985; Near, 1989; Palich et al., 1995; Sommer et al., 1996; Verkuyten et al., 1993) and numerous researchers have attempted to attribute these differences to differences in national values (Dorfman and Howell, 1988; Kirkman and Shapiro, 2001). However, Randall (1993) in a review of 27 global organisational commitment studies concluded that the research results did not support this theoretical perspective and Palich et al. (1995) found that only $2.7 \%$ of the variance in organisational commitment in their study could be explained by national values.

The existing research fails to explain the complexity of the relationship between national values and work attitudes (Kirkman and Shapiro, 2001). Few of the existing studies have explored the role that other interactions, such as organisational culture, may play in explaining the complex relationship between national values and work attitudes. Hofstede's (1980) research suggests that organisational culture strongly correlates with nationality. People within a country tend to share similar values and these values are subsequently reflected in the specific cultures of each country's business organisations. Hofstede and Peterson's (2000) revised model, based on questionnaire data from 116,000 respondents in 70 countries, identifies five major cultural dimensions: individualism/collectivism, power distance, uncertainty avoidance, 
masculinity/femininity and long-term/short-term orientation. A second frequently cited cross-cultural model grew out of Trompenaars' (1993) research based on data from 15,000 managers from 28 countries. Trompenaars identified five primary cultural dimensions: universalism vs. particularism; individualism vs. collectivism; neutral vs. affective; specific vs. diffuse; and achievement vs. ascription.

This research project addresses these issues by investigating the relationships among perceived organisational culture (practices), P-O fit, and employee work attitudes (job satisfaction and commitment) in two historically diverse national cultures, China and the USA - countries that numerous researchers (e.g., Hofstede, 1980; Trompenaars, 1993) have determined to have a high degree of cultural distance.

The purpose of this study was to explore whether or not the impact of globalisation is reflected in the organisational cultures of the USA and the People's Republic of China (PRC); two countries whose national values have historically been very different (Bond and Cheung, 1983; Hofstede and Peterson, 2000; Ronen and Shenkar, 1985; Trompenaar, 1993); thus shedding light on the convergence/divergence/cross-vergence debate as well as the determinants of job satisfaction and organisational commitment. This debate is of critical importance at a time when trade barriers between the East and the West are rapidly diminishing and East-West contact, communication, and collaboration are escalating. The rapid growth of multinational corporations, the fluid movement of workers across national boundaries, and the increasing popularity of off-shoring are organisational realities; however, little is known about how globalisation is impacting the organisational culture perceptions and preferences of employees in two countries that are assumed to have highly divergent values (e.g., individualism and collectivism).

This study, by investigating the organisational culture similarities and differences between two key players in the global marketplace, challenges the prevailing paradigm of cultural stability and lays the groundwork for future investigations into how and under what conditions people change their individual and collective values, the rate at which such changes may occur, and the processes by which these changes are integrated into organisational practices. In the present study we seek to contribute to the literature by investigating whether there is measurable cross-vergence in perceived and preferred organisational cultures in two countries with historically divergent national values. Previous cross-cultural research has relied primarily on assessing managerial perceptions of organisation culture. This research is unique in that the sample represents all levels of employees across a wide spectrum of industry types. The sample is also unique in that it includes a cross-representation of age, gender, and educational levels.

In responding to the recommendations of Finegan (2000) and Tepeci and Bartlett (2002), this study was designed to address previous P-O measurement problems. Specifically:

1 we analysed perceived organisational culture using our survey respondents' perceptions, rather than rely on the collective judgment of a second (non-participating) group of employees

2 we analysed the independent impact of perceived culture and preferred culture as well as the interaction between them

3 we treated organisational cultures and work attitudes as multi-dimensional constructs so that the relationship between different clusters of cultures and types of work attitudes could be examined. 
This research is also unique in that it includes both management and non-management employees from a wide spectrum of industry types in both China and the USA. Gender, age, length of service, and organisational level are used as control variables.

\section{Conceptual background and hypotheses}

An extant body of research defines and describes differences in national values (Hofstede, 1980; Kluckhohn, 1951; Kroeber and Parsons, 1958; Triandis, 1972; Trompenaars, 1993). Much of this research suggests that the values of a particular country are reflected in that country's organisational norms, values, and behaviours (Hofstede, 1980; Hofstede and Peterson, 2000; Schneider, 1988; Trompenaars, 1993). Recent research, however, suggests that the relationship between national values and organisational culture is much more complex than previously believed (House et al., 2004). Organisational culture emerges from the complex interactions of many internal and external factors (Ashmos et al., 2002; Boisot and Child, 1999; Brown and Eisenhardt, 1997; Frank and Fahrbach, 1999). An organisation's culture is not only influenced by the national values of its employees (Hofstede, 1980; Schneider, 1988; Trompenaars, 1993), it is also significantly influenced by the personality and values of the founder(s) (Harrison and Carroll, 1991; Schein, 1983, 1996). The founder's personality is reflected in his/her choice of organisational structure, and in the implicit and explicit policies and procedures which become the organisation's systems and strategies. These systems direct operational decision-making, thus shaping "the operating culture by influencing the behaviors that members come to believe are necessary and appropriate" [Cooke and Szumal, (2000), p.155]. As the organisation matures, the created culture in turn shapes the actions and styles of the leaders. "Through this dynamic ongoing process, the leader creates and is in turn shaped by the organizational culture" [Ogbonna and Harris, (2000), p.770]. Thus, an organisation's culture is a process of on-going sense making "determined by the organizational conditions and realities that members face on a day-to-day basis" [Cooke and Szumal, (2000), p.153].

\subsection{Organisational culture and work attitudes}

Much of the research that links national values to work attitudes fails to explain why certain national values correlate with job satisfaction and commitment. This suggests that there are other variables that mediate these relationships. Organisational culture may play such a role as a large body of research suggests that organisational culture is related to job satisfaction (Bhargava and Kelkar, 2000; Johnson and McIntye, 1998; Tzeng et al., 2002); commitment (Kanter, 1972; Lahiry, 1994; Moon, 2000; Odom et al., 1990; Perry and Porter, 1982); and turn-over intention (Kerr and Slocum, 1987; Kopelman et al., 1990; Mobley et al., 1979; Sheridan, 1992).

For example, Sheridan (1992) investigated the relationship between organisational culture and job retention for 904 employees in US public accounting firms over a six-year period. He found a firm's cultural values had a significant effect on the rates at which employees voluntarily terminated employment. Pool (2000) found that constructive cultures decreased job tension and increased job satisfaction, job performance, and job commitment while negative cultures (passive and aggressive) were associated with opposite outcomes. Johnson and McIntye (1998) found that job satisfaction was strongly 
correlated with cultures that emphasised empowerment, involvement and recognition. Tepeci and Bartlett (2002) found that employees' perception of their organisations' culture was a strong predictor of job satisfaction, intent to quit, and willingness to recommend their organisation as a good place to work.

International studies show similar results. Finegan (2000) investigated the relationship between personal values, organisational values, and commitment in a large Canadian petrochemical company. The results indicate that employees' perception of organisational values predicts commitment. In India, Bhargava and Kelkar (2000) found a negative correlation between job satisfaction and organisational cultures with highly centralised decision-making processes. They also found that positive perceptions of corporate culture were correlated with high job satisfaction and empowerment. Therefore, we posit:

Hypothesis 1 In both China and the USA there is a significant relationship between perceived organisational culture and work attitudes (i.e., job satisfaction and commitment).

\subsection{Perceived vs. preferred cultures}

Organisational culture serves as the foundation of an organisation's management system (Denison, 1990). Culture defines management practices - the norms that define how members of an organisation are to behave. The GLOBE researchers (House et al., 2004) suggest that management practices represent 'the way things are done' in a particular organisation while employee values define 'the way things should be done'.

Over time, an organisation's culture often shows little similarity to national values, the founder's values or even to the organisation's stated vision, mission, and values. In fact, an organisation's culture often shows little correlation to the espoused values of its members (Cooke and Szumal, 2000). For example, van Vianen (2000, p.136) found that in 68 Dutch organisations, $86 \%$ of the preferred culture scores were much higher than actual practice scores (perceived culture). House et al. (2004) also found that mean value scores (preferred) were higher than practice scores (perceived) on seven of the nine GLOBE cultural dimensions. Thus, we expect that:

Hypothesis $2 \mathrm{a} \quad$ In both China and the USA there is a significant gap between practices (perceived cultures) and values (preferred organisational cultures).

\subsection{P-O fit and work attitudes}

Kristof defines P-O fit as "the compatibility between people and organisations that occurs when: (a) at least one entity provides what the other needs, or (b) they share similar fundamental characteristics, or (c) both" (1996, p.5).

The concept of P-O fit recognises that both individual characteristics (e.g., values and expectations) interact with situational factors (e.g., cultural norms and values) to determine work attitudes and behaviours (Chatman, 1989; Finegan, 2000; O'Reilly et al., 1991; Schneider, 1987; Tepeci and Bartlett, 2002; Terborg, 1981).

Numerous studies have investigated the gap between 'as is' (perceived) and 'should be' (preferred) organisational cultures and the implications that this gap has for job satisfaction, organisational commitment, and turnover intention. For example, O'Reilly et al. (1991) analysed longitudinal data from accountants and MBA students, along with 
cross-sectional data from employees of US government agencies and public accounting firms. They found that person-culture fit predicts job satisfaction and organisational commitment one year after fit was measured and turnover after two years.

Vandenberghe (1999) replicated the O'Reilly et al. study in the Belgium healthcare industry in order to test the transferability of the model to other countries and industries. The results indicate that $\mathrm{P}-\mathrm{O}$ fit had a significant effect on nurse turn-over across a one-year period, with individuals who scored higher on fit being more likely to stay with their current employers.

Harris and Mossholder (1996) found that P-O fit discrepancies explained the significant variance in organisational commitment and optimism regarding the organisation's future. However, their results were not significant for job satisfaction, job involvement and job turnover intention.

Chow et al. (2002) examined the organisational cultures of US affiliated accounting firms and Taiwanese accounting firms. They investigated the importance of fit between perceived and preferred organisational cultures and the impact of fit on job satisfaction, commitment, and turn-over intention. Support was found for the impact of fit. Therefore, we expect:

Hypothesis $2 b \quad$ Job satisfaction and commitment are inversely related to the size of the perceived/preferred gap (P-O fit). Specifically, the smaller the gap, the higher the levels of job satisfaction and commitment for both Chinese and US employees.

\subsection{Cultural distance and work attitudes}

The research suggests that organisational cultures vary according to national values (Hofstede, 1980; House et al., 2004; Trompenaars, 1993). Hence, countries with similar national values would be expected to have more similarities in organisational culture than those that are more culturally distant; however, the current literature has inconclusive data regarding the relationships among national values, organisational culture, job satisfaction and commitment; and little research has been conducted in China, though numerous studies have compared levels of job satisfaction and commitment in the USA to other Asian countries with Confucian value systems. For example, Lincoln and Kalleberg (1985) found that job satisfaction was higher in the USA than in Japan and Luthans et al. (1985) found that US employees had higher levels of organisational commitment than employees in Japan or South Korea.

Conversely, Hui et al. (1995) identified a positive relationship between collectivism and job satisfaction and Palich et al. (1995) found that organisational commitment was negatively related to Hofstede's (1980) values of individualism and uncertainty avoidance and positively correlated with masculinity. Kirkman and Shapiro (2001) also found a tendency for higher levels of collectivism to be associated with greater job satisfaction and commitment and a tendency for lower levels of power distance to be associated with higher levels of commitment. However, cultural values did not explain all of the country differences.

Kirkman and Shapiro (2001) propose that psychological resistance moderates the national value/work attitude relationship. However, their results indicate that resistance only partially explains the difference in satisfaction and commitment across countries. 
Other moderators, such as P-O fit, may play a role in this complex equation. Therefore, we posit:

Hypothesis 3a The degree of $\mathrm{P}-\mathrm{O}$ fit is a stronger predictor of job satisfaction and organisational commitment than country.

Chatman (1989) and O'Reilly et al. (1991) found that P-O fit, as measured by profile analysis, predicted work attitudes. However, the difference scores used in calculating P-O fit have been criticised because they fail to reveal the unique contribution of each of the components of the overall score. Edwards points out that the "observed relationships may represent anything from the effect of a single component to the effects of all components combined" (1994, p.70). The independent contribution of personal or organisational values is ignored. Finegan concludes: "Without separate measures of person variables and organizational variables, it is difficult to address the entire question of whether behaviour is determined by person characteristics, organizational characteristics or their interaction" (2000, p.153). Furthermore, profile analyses disregard information on the direction of any preferred/perceived discrepancies (Edwards, 1993).

van Vianen (2000) examined the effects of two measures of fit on new hires' commitment and turnover intentions: P-O fit and P-P fit (which compared new hires' culture preferences to supervisors' and peers' culture preferences). The results show a significant, though complex relationship, between P-P fit, commitment and turnover intention. However, P-O fit was not significant. In fact, recent studies suggest that P-O fit may not be as strong a predictor of work attitudes as an organisation's perceived culture scores. Tepeci and Bartlett's (2002) hospitality industry study is an example. This study analysed the relationship of individual cultural preferences, organisational culture, and $\mathrm{P}-\mathrm{O}$ fit to job satisfaction, intent to quit, and willingness to recommend the organisation as a good place to work. Their results found a positive relationship between P-O fit and the three dependent variables. However, P-O fit did not provide predictive value beyond that explained by measures of perceived organisational culture. Finegan (2000) had similar findings. Therefore, we expect:

Hypothesis $3 \mathrm{~b}$ Perceived culture is a stronger predictor of job satisfaction and organisational commitment than either country or P-O fit.

\section{Methods}

\subsection{Sample and procedures}

A total of 1,838 Chinese and US (846 and 992 respectively) employees were sampled from $111 \mathrm{PRC}$ and 129 US organisations. The respondents represent a wide variety of industries including manufacturing, information technology, banking, insurance, pharmaceuticals, and telecommunications. The organisations ranged in size from small entrepreneurial organisations with fewer than 20 employees to large multinationals with tens of thousands of employees. Some of these organisations are privately held, some are publicly traded and a few are either state-owned enterprises (SOEs) or non-profit service organisations. Organisational level ranged from entry-level production, customer service, and administrative positions to senior level executives. See Table 1 for variables, means and correlations. 
Table 1 Means and correlations

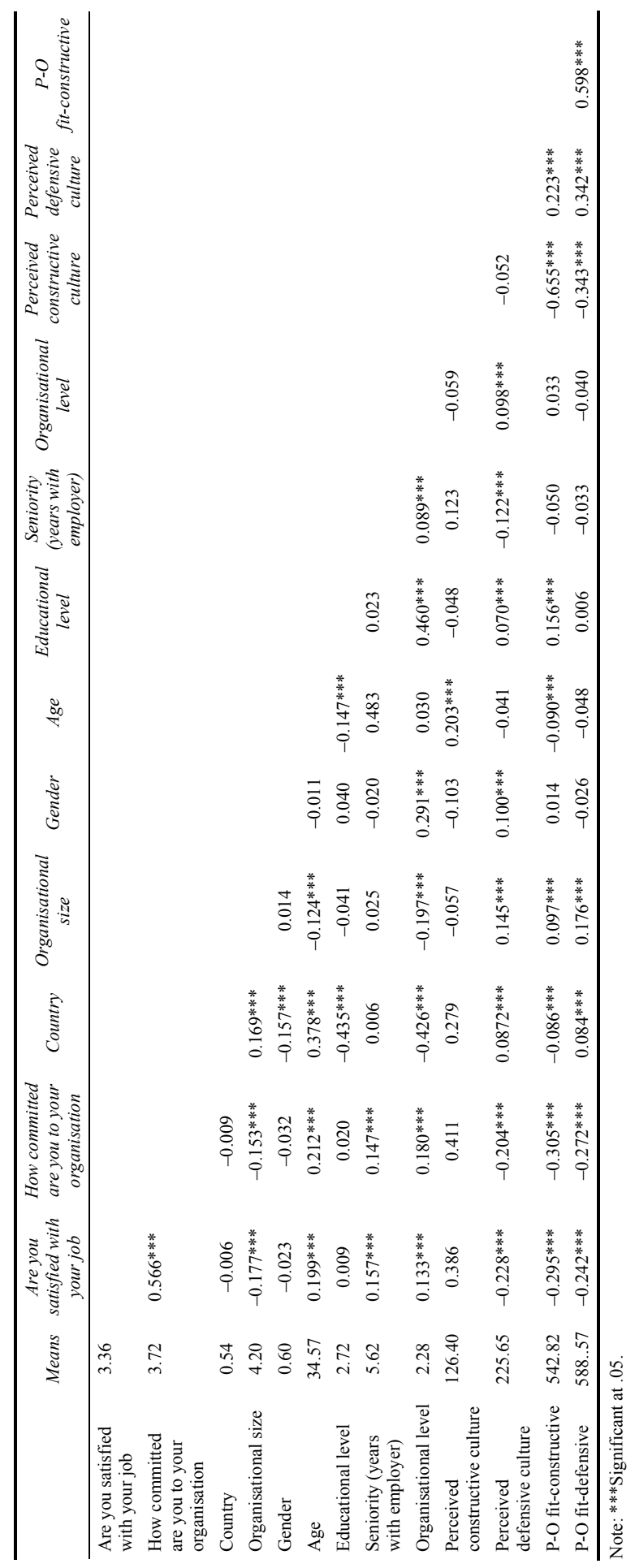




\subsection{Measures}

The organisational culture literature is challenged by a variety of measurement problems. For example numerous researchers (Chatman, 1989; Caldwell and O'Reilly, 1990; O'Reilly et al., 1991) have calculated P-O fit by comparing personal value preferences (preferred culture) to a pre-identified organisational culture profile (obtained from a different group of respondents). Their research design (profile analysis) is grounded in an assumption that culture is an objective phenomenon. This assumption disregards a growing body of research that suggests that work attitudes are determined by the subjective experiences of individuals (van Vianen, 2000). Finegan explains the problem: "an individual's subjective perception is more likely to determine his or her attitudes or behaviour than the collective perceptions of others" (2000, p.151). Thus, our study collected perceived and preferred culture ratings from the same population.

\subsubsection{Organisational culture}

Culture instruments fall into one of two categories: normative or ipsative (Chatman, 1989). Normative measurements require respondents to rate the extent to which they agree with a set of statements while ipsative methods require respondents to rank or make forced choice selections among values using a Q-sort approach (the type used in profile analysis). Edwards (1991, 1994) and Finegan (2000) are critical of ipsative measures because they are not designed around an interval-level scale and, thus, do not define the distance between component measures (values). Normative commitment (Bolon, 1997) is the commitment that a person believes that they have to the organisation or their feeling of obligation to their workplace. Therefore, for the purposes of this study, we selected a normative measure, the organisational culture inventory (OCI).

The OCI (Cooke and Lafferty, 1987) is a paper-pencil instrument copyrighted and published by Human Synergistics, International. The OCI has been administered to over two million respondents in thousands of organisations worldwide (Cooke and Szumal, 2000). Originally published in English, it is now available in 13 languages, including Mandarin Chinese. Extensive reliability and validity testing has been performed [Cooke and Szumal, (1993), p.1299].

The OCI is comprised of 120 brief phrases that the respondent rates using a five-point, Likert-type scale. A ' 1 ' rating means 'not at all like my organisation'; a ' 5 ' rating is defined as 'to a very great extent'. Items include: 'show concern for the needs of others', 'accept goals without questioning them', 'encourage others', 'do what is expected', 'avoid confrontations', 'accept the status quo', and 'think in unique and independent ways'. Respondents rated each of these items twice. The first rating indicates how much of the stated behaviour is necessary for success in the current (perceived) culture; the second rating indicates how much of this same behaviour would be required in an ideal (preferred) work environment. The $120 \mathrm{OCI}$ items were factored into 12 culture styles (Cooke and Lafferty, 1987).

In the initial OCI studies by Cooke and Lafferty (1987) and Cooke and Szumal (1993), the 12 OCI culture styles were further factored, grouping the 12 culture styles into three separate clusters of organisational cultures: 
1 constructive cultures where members are encouraged to interact with others and approach tasks in ways that will enable them to fulfil their satisfaction needs (achievement, self-actualising, humanistic-encouraging, and affiliative culture styles

2 passive/defensive cultures where members tend to act defensively in an attempt to protect their own security (approval, conventional, dependent, and avoidance culture styles)

3 aggressive-defensive cultures where members are encouraged to approach tasks aggressively in order to protect their status and security (oppositional, power, competitive, and perfectionist culture styles).

Cooke and Lafferty's initial factor analysis was performed on managers (Cooke and Lafferty, 1987). When we repeated the factor analysis on the managerial subset within our sample, we obtained similar groupings: one constructive culture cluster and two defensive culture clusters. However, when non-supervisory employees were added, the loadings suggest there are only two distinct culture clusters: constructive and defensive. Constructive cultures are where members are encouraged to interact with others and approach tasks in ways that will enable them to fulfil their satisfaction needs. Defensive cultures are where members tend to act defensively in an attempt to protect their own security and status. As our sample includes employees from all levels within an organisation, we have used only these two culture categories (see Table 2).

Table 2 Factor analysis of OCI when all job levels are added

\begin{tabular}{lcc}
\hline \multicolumn{3}{c}{ Rotated component matrix } \\
\hline OCI 1 & Constructive & Defensive \\
OCI 2 & -0.11 & 0.857 \\
OCI 3 & -0.041 & 0.879 \\
OCI 4 & 0.755 & 0.112 \\
OCI 5 & 0.785 & -0.074 \\
OCI 6 & 0.78 & 0.18 \\
OCI 7 & 0.723 & -0.423 \\
OCI 8 & 0.71 & -0.147 \\
OCI 9 & 0.831 & -0.117 \\
OCI 10 & 0.785 & -0.039 \\
OCI 1 & 0.684 & 0.328 \\
OCI 12 & 0.11 & 0.864 \\
Rotation converged in three iterations & 0.82
\end{tabular}

\begin{tabular}{lc}
\hline \multicolumn{2}{c}{ Component transformation matrix } \\
\hline Constructive & Defensive \\
\hline 0.992 & -0.129 \\
0.129 & 0.992 \\
Component 12 & \\
\hline
\end{tabular}

Notes: Extraction method: principal component analysis.

Rotation method: varimax with Kaiser normalisation. 


\subsubsection{Job satisfaction}

Tett and Meyer's (1993) meta-analysis demonstrates that global measures of job satisfaction were equally as strong a predictor of behavioural outcomes (e.g., voluntary turnover) as were sum-of-facet measures. Wanous et al.'s (1997) meta-analysis found that single-item measures of overall job satisfaction demonstrated convergent validity (.63) with sum-of-facet scales and had a minimum reliability estimate of .70. They concluded that global measures were more robust than scale measures. Scarpello and Campbell (1983) also found that for overall job satisfaction, a single-item global measure may be a better predictor than a summation of facet responses. Therefore, we measured job satisfaction using a single global item (i.e., "How satisfied are you with your job?"). The five response options ranged from 'not at all' to 'to a very great extent'.

\subsubsection{Organisational commitment}

Numerous researchers (Morrow, 1983; O’Reilly and Chatman, 1986; Staw, 1977) have noted the need to differentiate organisational commitment from other related psychological constructs. Although a variety of theoretical and operational definitions have been used in the literature, the central theme is psychological attachment to an organisation. Caldwell et al. (1990) identified two underlying dimensions of commitment, which they refer to as normative (commitment based on shared values) and instrumental (commitment based on involvement exchanged for specific rewards). Meyer and Allen (1991) argue for three types of organisational commitment-affirmative: a positive emotional attachment to the organisation, normative: based on feelings of commitment, and continuance: the different costs of leaving an organisation. As this study is primarily concerned with shared values, our questions are directed to issues of normative commitment. The four-items were adapted from the normative commitment scales of previous studies (Caldwell et al., 1990; O'Reilly and Chatman, 1986). Example items included: "How committed are you to your organisation's values, goals and practices?" and "Would you recommend your organisation as a good place to work?" The five response options ranged from 'not at all' to 'to a very great extent'.

In addition, a new variable called P-O fit was created by summing the squared differences between the perceived OCI score and the respective preferred OCI score. Scores were squared to remove any negative scores plus give the differences between larger OCI values more weight.

\subsubsection{Control variables}

Previous research suggests that age, education, job level and tenure are predictors of job satisfaction (Bedeian et al., 1992; Robie et al., 1998) as well as commitment (Mathieu and Zajac, 1990). Therefore, we collected five demographic and organisational items: three categorical (gender, organisational level, and organisational size) and two continuous (age and length of service). 
The impact of organisational culture and P-O fit on job satisfaction

Table 3 Hierarchical regression for job satisfaction

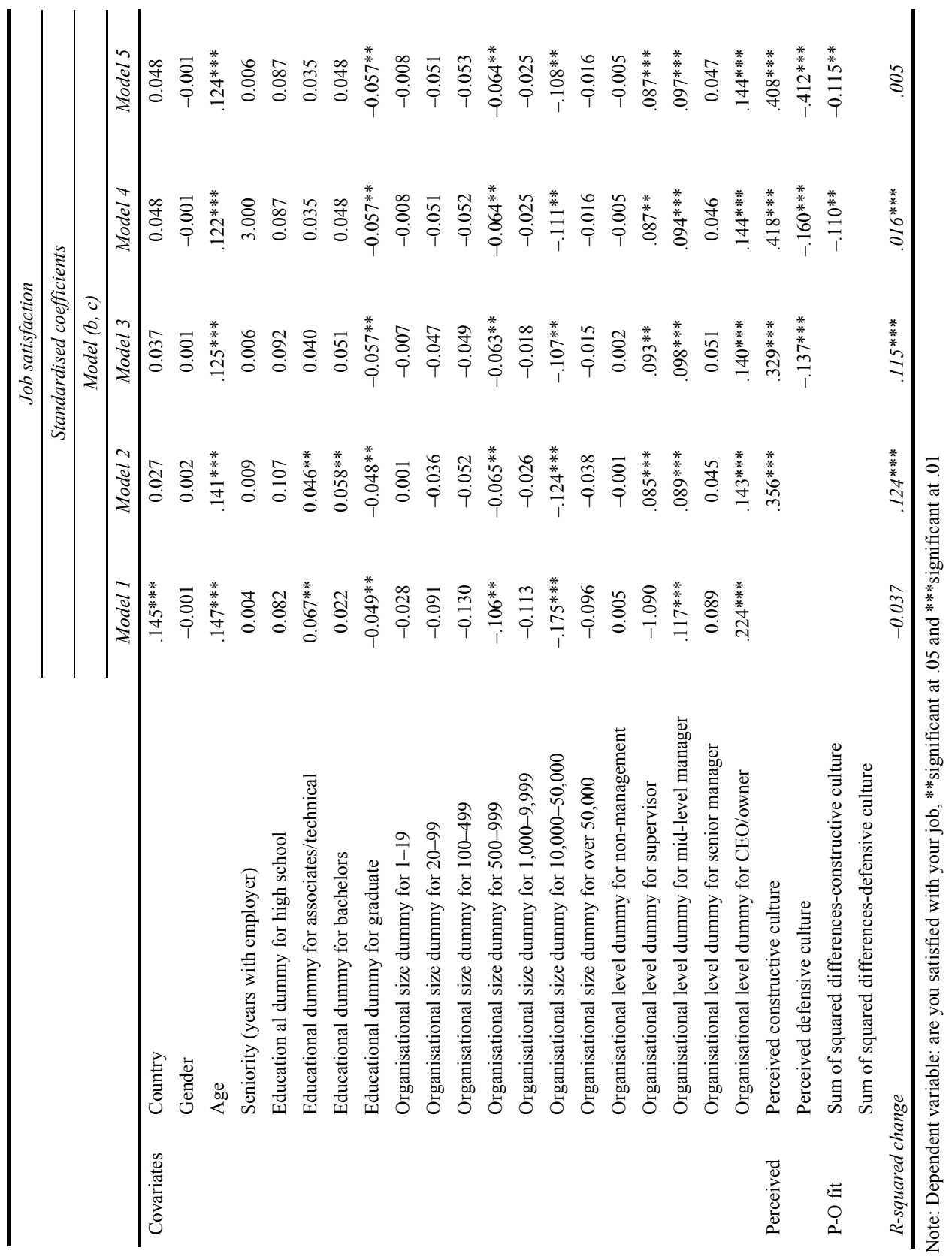


Table 4 Hierarchical regression for organisational commitment

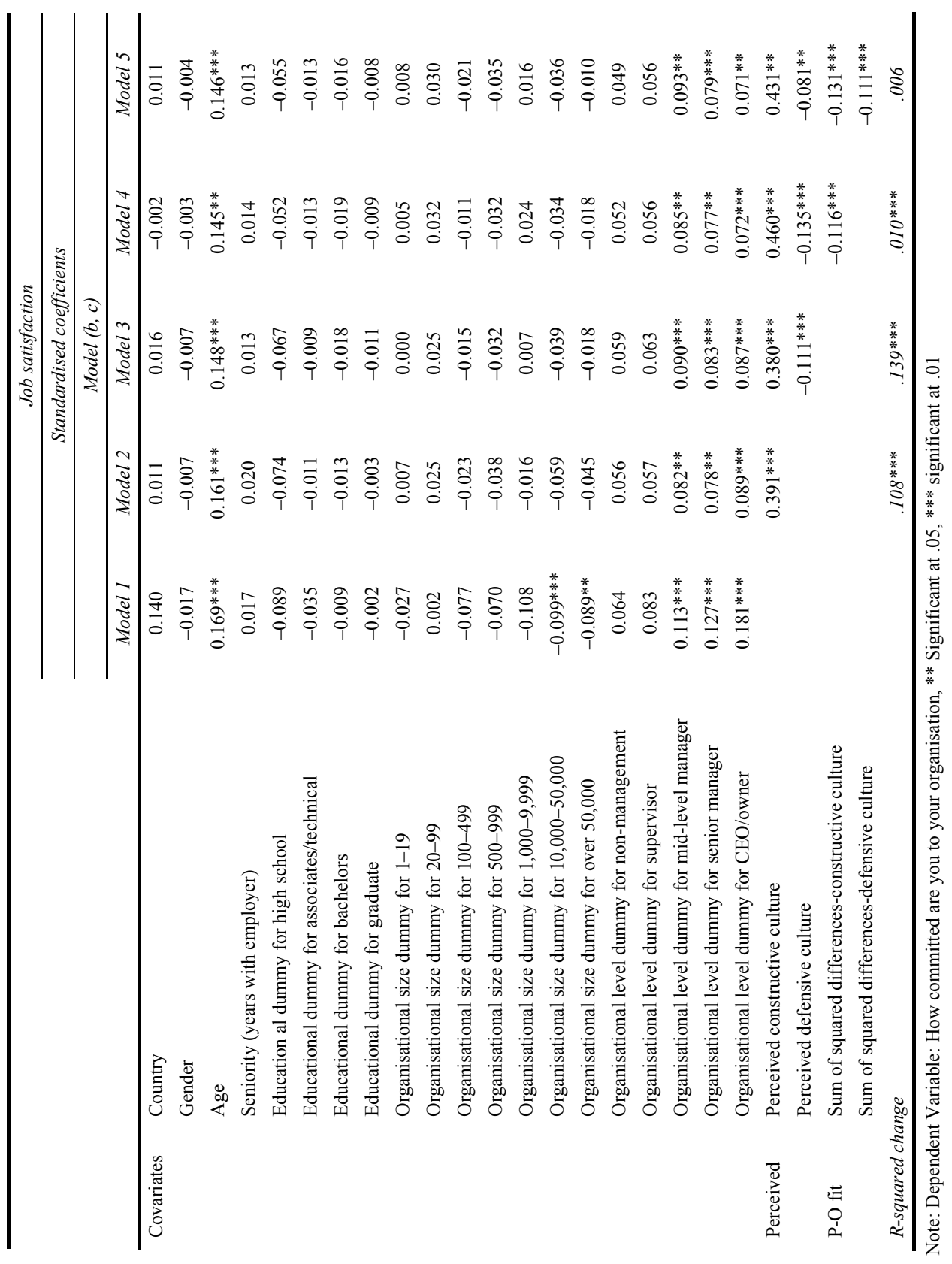




\section{Results}

Commitment and job satisfaction are strongly correlated (.566). The correlations and means can be found in Table 1. Country, gender, and educational level have no significant correlation with work attitudes (job satisfaction and commitment). Age, seniority, and organisational level have weak positive correlations to work attitudes $(0<r<.30)$. Perceived constructive culture has a moderate positive correlation to work attitudes $(.30<r<.50)$. Perceived defensive culture, $\mathrm{P}-\mathrm{O}$ fit constructive culture, and $\mathrm{P}-\mathrm{O}$ fit defensive culture have weak negative correlations to work attitudes $(0>r>-.30)$. The only other strong correlation $(.5<r<1.0)$ is between organisation level and education.

A hierarchal regression model was employed to test Hypotheses 1, 2b, 3a and $3 \mathrm{~b}$. This technique was principally used to determine the impact of different variables (change in the adjusted R-square) as they are entered into the model. P-O fit was created by summing the squared differences between the perceived OCI score and the respective preferred OCI score. Scores were squared to remove any negative scores plus give the differences between larger OCI values more weight.

Five hierarchical regression models were run with job satisfaction and commitment as the dependent variables. Each model adds an additional explanatory variable(s) to test the change in R-square. Standardised coefficients were examined to approximate which of the variables had the strongest effect. Results can be found in Tables 3 and 4.

\subsection{Results for job satisfaction}

In the model displayed in Table 3 (job satisfaction), all the demographic controls were entered which include country, gender, age, seniority, organisational level, educational level, and organisational size. The R-square change for the first set of variables was .124 (significant at .01)

The second model added perceived constructive culture. It added an additional explanatory power to R-square of .115 (also significant at .01). Perceived constructive culture is, in fact, significant in all the models and has the strongest standardised coefficient of any variable in any model.

The third model adds perceived defensive culture. This variable increases R-square by .016 and is significant at .01. Perceived defensive culture is significant throughout all the models, and its standardised coefficient is negative. This indicates that as perceived defensive culture increases, job satisfaction decreases.

The fourth model adds P-O fit for constructive culture. This adds only .005 to $\mathrm{R}$-squared and is not significant. The fifth and final model adds P-O fit for defensive culture. This adds .001 to R-squared and is not significant. Neither of the P-O fits are significant for job satisfaction in the models at .01 , but $\mathrm{P}-\mathrm{O}$ fit constructive is significant at .05 .

In the final model (the model used to determine the value of the coefficients), age and three of the organisational levels were significant at .01. Country of origin, gender, seniority, all educational levels (except graduate degree) and all organisational sizes (except 500-99 and $10 \mathrm{~K}-50 \mathrm{~K}$ ) were not significant. Perceived constructive culture had the highest standardised value. Perceived defensive culture was the weakest of the significant variables. Three of the five organisational levels were significant, but weak relative to perceived culture and $\mathrm{P}-\mathrm{O}$ fit. 


\subsection{Organisational commitment results}

In the commitment model shown in Table 4, all the covariates were entered, which include country, gender, age, seniority, organisational level, educational level, and organisational size. The R-square change for the first set of variables was .108 (and was significant at .01).

The second model added perceived constructive culture. It added an additional explanatory power to R-square of .139 (also significant at .01). Perceived constructive culture is significant in all the models, and it is also the strongest standardised coefficient of any variable in any model.

The third model adds perceived defensive culture. This variable adds .010 to $\mathrm{R}$-squared and is significant at .01. Perceived defensive culture is not significant throughout all the models at .01 , but it is at .05 . It holds significance at .01 until P-O fit defensive is added.

The fourth model adds P-O fit for constructive culture. This adds only .006 to $\mathrm{R}$-squared and is not significant. The fifth model includes $\mathrm{P}-\mathrm{O}$ fit for defensive culture. This adds .007 to R-squared and is not significant. P-O fit defensive is significant at .05 in the final model. In the final model, age was the only covariate that was significant. Also, in the final model, two of the organisational levels are significant.

As in the job satisfaction model, country, gender, educational level, seniority and organisational size are not significant. The strongest variable was perceived constructive culture. The second and third strongest variables are age and P-O fit constructive culture, respectively. The remaining significant variables are $\mathrm{P}-\mathrm{O}$ fit defensive culture and perceived defensive culture.

Table 5 Repeated measures ANOVA: gap between perceived and preferred

\begin{tabular}{lcccc}
\hline Effect & Test & Value & $F$ & Sig. \\
\hline \multicolumn{1}{c}{ Multivariate tests for constructive cultures gap (perceived vs. preferred) } & \\
\hline Constructive culture gap & Wilks' Lambda & 0.032 & $34.776^{* * *}$ & 0.000 \\
Constructive culture * country & Wilks' Lambda & 0.002 & 2.040 & 0.154 \\
Constructive culture * gender & Wilks' Lambda & 0.001 & 1.541 & 0.215 \\
Constructive culture * age & Wilks' Lambda & 0.001 & 0.585 & 0.444 \\
Constructive culture * seniority & Wilks' Lambda & 0.002 & 1.940 & 0.164 \\
Constructive culture * organisational size & Wilks' Lambda & 0.001 & 1.501 & 0.221 \\
Constructive culture * education & Wilks' Lambda & 0.026 & $28.053 * *$ & 0.000 \\
\hline \multicolumn{1}{c}{ Multivariate tests for defensive cultures gap (perceived vs. preferred) } & \\
\hline Defensive culture gap & Wilks' Lambda & 0.053 & $54.812 * * *$ & 0.000 \\
Defensive culture * country & Wilks' Lambda & 0.148 & $170.566^{* * *}$ & 0.000 \\
Defensive culture * gender & Wilks' Lambda & 0.001 & 0.583 & 0.446 \\
Defensive culture * age & Wilks' Lambda & 0.000 & 0.062 & 0.803 \\
Defensive culture * seniority & Wilks' Lambda & 0.000 & 0.111 & 0.739 \\
Defensive culture * organisational size & Wilks' Lambda & 0.044 & $45.246^{* * *}$ & 0.000 \\
Defensive culture * education & Wilks' Lambda & 0.020 & $20.400^{* * *}$ & 0.000 \\
\hline
\end{tabular}

Note: $* * *$ Significant at .01 
In order to test Hypothesis 2a, a multivariate repeated measures model ANOVA (RMM) was constructed and run (see Table 5). In this case, it is similar to a paired t-test (looking for differences between two related measures), but also allows us to control for the covariates as well as measure their interactions. The first RMM model was created to test for a gap between perceived and preferred constructive culture. The second RMM model was created to test for a gap between perceived and preferred defensive culture.

There is a significant gap (at the .01 level) between perceived and preferred cultures for the constructive culture cluster. Country (USA or PRC) does not have a significant effect on the gap between perceived and preferred cultures. Gender, age, seniority, organisational size, and organisational level also do not have significant interactions with the constructive culture gap. Education does have a significant interaction.

There is also a significant gap (at the .01 level) between perceived and preferred cultures in the defensive culture cluster. In addition, difference in country has a significant effect for defensive culture. Gender, age, and seniority do not have a significant interaction with the defensive culture gap. Organisation size and education are significant. Thus, we found strong support for Hypothesis $2 \mathrm{a}$. There is a significant gap between perceived and preferred organisational cultures in both China and the USA, though the interactions vary somewhat by country.

\section{Discussion}

The purpose of this study was to investigate the impact of organisational culture and P-O fit on job satisfaction and organisational commitment in two countries with historically different national values. Previous research has failed to explain the complexity of the relationship between work attitudes, national values, organisational culture, and P-O fit (Palich et al., 1995; Randall, 1993).

In summary, we found strong support for Hypothesis 1. There is a significant relationship between perceived organisational culture and work attitudes. Perceived constructive culture has a strong positive relationship with both job satisfaction and organisational commitment. Perceived defensive culture also has a strong relationship with culture (albeit not as strong as constructive). It is important to note that the relationship between perceived defensive culture and work attitudes is negative.

We found partial support for Hypothesis $2 \mathrm{~b}$, which hypothesised that work attitudes are related to P-O fit. P-O fit is not a significant predictor of job satisfaction; however, our results support P-O fit as a significant predictor of organisational commitment, though P-O fit adds little explanatory power to either model.

We found more support for Hypothesis 3a. P-O fit for constructive culture is a stronger predictor than country for job satisfaction. However, P-O fit for defensive culture and country are not significant. In regards to organisational commitment, both of the $\mathrm{P}-\mathrm{O}$ fits (constructive and defensive) are significant as well as negative.

We found strong support for Hypothesis $3 \mathrm{~b}$, which hypothesised that perceived culture is a stronger predictor of work attitudes than either country or P-O fit. For both job satisfaction and commitment, perceived constructive culture is significant and has the strongest effect in both models.

The results of this study suggest that an organisation's perceived culture is the most significant predictor of job satisfaction and organisational commitment - regardless of country, gender or length of service. Perceived organisational culture as manifested in 
day-to-day operating practices is the strongest predictor of the targeted work attitudes (job satisfaction and organisational commitment) with constructive (positive) cultures providing the strongest standardised coefficient across all of our models.

During times of societal upheaval, individual values may shift at a much faster rate than organisational structures. Even though both traditional and contemporary change theories suggest that value shifts are possible, there are a variety of institutional, political, and sociological factors that mediate this change. Consequently, a gap, or at least a significant time delay, between a change in national values and a corresponding change in organisational culture would be expected. A tendency for structural inertia inhibits cultural change - even when individual members of the system desire it (Katz and Katz, 1978). Therefore, shifts in national values, even when they are widely held, may not immediately be transferred into organisational practices and, thus, reflected in an organisation's culture.

Due to a complex variety of psychological, sociological, and organisational factors, the cultures of most organisations are not aligned with the espoused values of the members (Cooke and Szumal, 2000). There is typically a disconnect between members' preferred cultures and the experienced realities of their day-to-day (perceived) organisational cultures. As the national values of employees in the PRC and the USA cross-verge, it would be expected that their shared values would translate into a shared preference for an ideal culture - even though such a culture may be significantly different from the current organisational reality in either country.

Our results suggest that positive organisational cultures are the key driver of job satisfaction and organisational commitment regardless of an employee's county of origin (national values), gender or length of service. It is important to point out that perceived organisational culture (current practices) appear to significantly impact work attitudes regardless of the cultural preferences of the respondent. Equally as important is the fact that perceived culture has stronger predictive value that $\mathrm{P}-\mathrm{O}$ fit. This lends supports to previous research (Finegan, 2000; Tepecci and Bartlett, 2002; van Vianen, 2000).

The convergence of Chinese and US preferred workplace values found in this study is not, however, the same as the one-directional concept of convergence typically used in the cross-cultural literature. The convergent theorists have traditionally assumed that industrialisation causes developing countries to adopt Western values. This assumption is not supported by our data, perhaps at least in part due to the fact that cross-cultural convergence models fail to discriminate between business practices and societal values. While developing countries such as China may increasingly study and adopt Western business models and practices, management practices relating to these styles are not congruent with the emerging values of either country's workforce (as indicated by the OCI ideal scores). The similarity of 'preferred' values in two countries with previously divergent value systems does not necessarily imply that one culture is adopting the other's values, but rather that both may be learning from each other while also adapting to a changing external environment. The non-linearity of such a process is congruent with the change processes of complex living systems as modelled in the theories of punctuated equilibrium and complexity.

Even though P-O fit is not a strong predictor of work attitudes, it is important to point out that there are significant gaps between respondents' preferred and perceived culture ratings. Both the constructive and defensive cultures show a significant gap between what employees want (preferred) and what they have (perceived). The larger the gap between preferred and perceived cultures, the lower the job satisfaction and organisational 
commitment ratings. Perceived constructive culture, along with the demographic variables, had the strongest explanatory power for both job satisfaction and organisational commitment.

\subsection{Theoretical and practical implications}

The most important practical implication is the need for new models and methods for helping managers develop constructive organisational cultures. Our findings suggest that people who work in constructive cultures have higher levels of job satisfaction and organisational commitment; yet, we also found a significant gap between the desire for constructive cultures and the prevalence of them. Numerous studies have found a relationship between work attitudes and performance (Angle and Perry, 1981; Burke, 1995; Hallowell et al., 1996; Organ and Konovsky, 1989; Mathieu and Zajac, 1990; Schmit and Allscheid 1995). Thus, new ways of developing constructive organisational cultures should be a top priority for business schools and corporate management development programmes.

This study also suggests that perceived culture is a much stronger predictor of work attitudes than P-O fit. As the P-O fit methodology is fraught with measurement challenges (Edwards, 1994; Finegan, 2000); and as numerous other studies (Finegan, 2000; Tepeci and Bartlett, 2002; van Vianen, 2000) have found it to be a weak predictor, we recommend that future studies simplify the measurement process and focus only on assessing respondents' perceptions of their current culture.

The results of this study also support the recent GLOBE report's (House et al., 2004) emphasis on the importance of differentiating between values (preferred behaviours) and practices (current behaviours). Even though Hofstede and Peterson (2000, p.412) acknowledge that "practices more than values lie at the root of organisational culture", Hofstede's scales themselves do not differentiate cultural practices from cultural values (House et al., 2004). The results of our study also reinforce other GLOBE findings that suggest that there are universally endorsed leadership preferences [House et al., (2004), pp.677-678]. This has important positive implications for training and assigning expatriate managers in multi-national corporations.

\subsection{Limitations and future research}

Based on Taras and Steel (2008), "Developing an effective cross-cultural survey instrument appears to be extremely difficult due to a number of challenges ranging from such theoretical issues as the definition of culture to practical problems such as translation of the instrument items into foreign languages". All cross-cultural research presents language challenges. In this study, the primary research instrument, the OCI was published in both English and Mandarin Chinese. However, due to the abstraction level of the behaviours rated (e.g., 'point out flaws' or 'be hard to impress'), both US and Chinese respondents typically asked clarification questions. As respondents from both countries asked similar questions, it appears that their questions were not attributable to translation errors or instrument ethnocentrism. The data collection procedure was standardised in each country. Either one of the researchers or a trained research assistant was present during the survey administration process. There were no language translation issues involved in the scoring process as all response options used pre-coded numerical scales. A second limitation is the potential selection bias that occurs when the sample is 
non-random and also relatively small. However, due to the age, gender, role, industry, and geographic diversity of our sample, this concern seems improbable. A third limitation is mono-method bias. Self-report and mono-method bias often threaten the validity of research conducted in business settings and thus hinder the development of theories of organisational behaviour (Donaldson and Grant-Vallone, 2002). This can distort conventional parameter estimates of the substantive relationships between constructs measured in organisational behaviour research. A remedy for mono-method bias is to implement multiple measures of key constructs and try to demonstrate (perhaps through a pilot or side study) that the measures you use behave as you theoretically expect them to. This is somewhat controlled in the fact that our instrument (OCI) uses several constructs to create the constructive and defensive factors (see factor analysis and description of OCT instrument) create great bias in this study and study methods, however must still be considered a limitation.

We recommend that this study be replicated in other countries to determine the robustness of our findings. Specifically, are constructive organisational cultures always a stronger predictor of work attitudes than P-O fit and does this hold across additional countries? We also suggest that future research incorporate facet-specific measures of job satisfaction and instrumental as well as normative measure of organisational commitment. Finally, we recommend that organisational leaders use these findings to formulate human resource policies and practices that are congruent with the values and behaviours of constructive cultures.

\section{References}

Agarwal, S. (1993) 'Influence of formalization on role stress, organizational commitment, and work alienation of salespersons: a cross-national comparative study', Journal of International Business Studies, Vol. 24, pp.715-739.

Angle, H.L. and Perry, J.L. (1981) 'An empirical assessment of organizational commitment and organizational effectiveness', Administrative Science Quarterly, Vol. 26, pp.1-14.

Ashmos, D., Duchon, D., McDaniel, R., Jr. and Huonker, J. (2002) 'What a mess! Participation as a simple managerial rule to 'complexity' organizations', Journal of Management Studies, Vol. 39, No. 2, pp.189-206.

Bedeain, A.G., Ferris, G.R. and Kacmar, K.M. (1992) 'Age, tenure, and job satisfaction: a tale of two perspectives', Journal of Vocational Behavior, Vol. 27, pp.33-48.

Begley, T.M. and Czajka, J.M. (1993) 'Panel analysis of the moderating effects of commitment on job satisfaction, intent to quit, and health following organizational change', Journal of Applied Psychology, Vol. 78, pp.552-556.

Bhargava, S. and Kelkar, A. (2000) 'Prediction of job involvement, job satisfaction, and empowerment from organizational structure and corporate culture', Psychological Studies, Vol. 45, No. 1, pp.43-50.

Boisot, M. and Child, J. (1999) 'Organizations as adaptive systems in complex environments: the case of China', Organization Science, Vol. 10, No. 3, pp.237-252.

Bolon, D.S. (1997) 'Organizational citizenship behavior among hospital employees: a multidimensional analysis involving job satisfaction and organizational commitment', Hospital \& Health Services Administration, Vol. 42, No. 2, pp.221-241.

Bond, M.H. and Cheung, T. (1983) 'College students' spontaneous self-concept: the effect of culture among respondents in Hong Kong, Japan, and the United States', Journal of Cross-Cultural Psychology, Vol. 14, pp.153-171. 
Brown, S. and Eisenhardt, K. (1997) 'The art of continuous change: linking complexity theory and time-paced evolution in relentlessly shifting organizations', Administrative Science Quarterly, Vol. 42, pp.1-34.

Burke, R.J. (1995) 'Management practices, employees' satisfaction and perceptions of quality service', Psychological Reports, Vol. 77, pp.748-750.

Caldwell, D. and O'Reilly, C. (1990) 'Measuring person-job fit using a profile comparison process', Journal of Applied Psychology, Vol. 75, pp.648-657.

Caldwell, D.F., Chatman, J.A. and O'Reilly, C.A. (1990) 'Building organizational commitment: a multifirm study', Journal of Occupational Psychology, Vol. 63, No. 3, pp.245-261.

Carsten, J.M. and Spector, P.E. (1987) 'Unemployment, job satisfaction, and employee turnover: a meta-analytic test of the Muchinsky model', Journal of Applied Psychology, Vol. 72, pp.374-381.

Chatman, J.A. (1989) 'Improving interactional organizational research: a model of person-organization fit', Academy of Management Review, Vol. 14, pp.333-349.

Chow, C., Harrison, G., McKinnon, J. and Wu, A. (2002) 'The organizational culture of public accounting firms: evidence from Taiwanese local and US affiliated firms', Accounting, Organizations \& Society, Vol. 27, Nos. 4-5, pp.347-360.

Clugston, M., Howell, J.P. and Dorfman, P.W. (2000) 'Examining organizational commitment across cultural dimensions', Journal of Management, Vol. 26, pp.5-30.

Cooke, R. and Lafferty, J. (1987) Organizational Culture Inventory, Human Synergistics, Plymouth, MI.

Cooke, R. and Szumal, J. (1993) 'Measuring normative beliefs and shared behavioral expectations in organizations: the reliability and validity of the organizational culture inventory', Psychological Reports, Vol. 72, pp.1299-1330.

Cooke, R. and Szumal, J. (2000) 'Using the organizational culture inventory to understand the operating cultures of organizations', in Ashkanasy, N., Wilderom, C. and Peterson, M. (Eds.): Handbook of Organizational Culture \& Climate, pp.147-162, Sage Publications, Thousand Oaks, CA.

Cotton, J.L. and Tuttle, J.M. (1986) 'Employee turnover: a meta-analysis and review with implications for research', Academy of Management Review, Vol. 11, pp.55-70.

Denison, D.R. (1990) Corporate Culture and Organizational Effectiveness, John Wiley \& Sons, New York.

Dickter, D.N., Roznowski, M. and Harrison, D.A. (1996) 'Temporal tempering: an event history analysis of the process of voluntary turnovers', Journal of Applied Psychology, Vol. 81, pp.705-716.

Donaldson, S.I. and Grant-Vallone, E.J. (2002) 'Understanding self-report bias in organizational behavior research', Journal of Business and Psychology, Vol. 17, No. 2, pp.245-262.

Dorfman, P.W. and Howell, J.P. (1988) 'Dimensions of national culture and effective leadership patterns: Hofstede revisited', in Farmer, R.N. (Ed.): Advances in International Comparative Management, Vol. 3, pp.127-150, JAI Press, Greenwich, CT.

Edwards, J.R. (1991) 'Person-job fit: a conceptual integration, literature review, and methodological critique', in Copper, C.L. and Robertson, I.T. (Eds.): International Review of Industrial and Organizational Psychology, Vol. 6, pp.283-357, Wiley, New York.

Edwards, J.R. (1993) 'Problems with the use of profile similarity indices in the study of congruence in organizational research', Personal Psychology, Vol. 46, pp.641-665.

Edwards, J.R. (1994) 'The study of congruence in organizational behavior research: critique and a proposed alternative', Organizational Behavior and Human Decision Processes, Vol. 58, pp.51-100.

Finegan, J.E. (2000) 'The impact of person and organizational values on organizational commitment', Journal of Occupational \& Organizational Psychology, Vol. 73, No. 2, pp.149-169. 
Frank, K. and Fahrbach, K. (1999) 'Organization culture as a complex system: balance and information in models of influence and selection', Organization Science, Vol. 10, No. 3, pp.253-277.

Gellatly, I.R. (1995) 'Individual and group determinants of employee absenteeism: test of a causal model', Journal of Organizational Behavior, Vol. 16, pp.469-485.

Hackett, R.D. and Guion, R.M. (1985) 'A reevaluation of the absenteeism-job satisfaction relationship', Organizational Behavior and Human Decision Processes, Vol. 35, pp.340-381.

Hallowell, R., Schlesinger, L.A. and Zornitsky, J. (1996) 'Internal service quality, customer and job satisfaction: linkages and implications for management', Human Resources Planning, Vol. 19, No. 2, pp.20-31.

Harris, S.G. and Mossholder, K.W. (1996) 'The affective implications of perceived congruence with culture dimensions during organizational transformation', Journal of Management, Vol. 22, No. 4, pp.527-547.

Harrison, J. and Carroll, G. (1991) 'Keeping the faith: a model of cultural transmission in formal organizations', Administrative Science Quarterly, December, pp.552-582.

Hofstede, G. (1980) Culture's Consequences: International Differences in Work-related Values, Sage, Beverly Hills, CA.

Hofstede, G. and Peterson, M. (2000) 'Culture: national values and organizational practices', in Ashkanasy, N., Wilderom, C. and Peterson, M. (Eds.): Handbook of Organizational Culture \& Climate, pp.147-162, Sage Publications, Thousand Oaks, CA.

House, R., Hanges, P., Javidan, M., Dorfman, P. and Gupta, V. (Eds.) (2004) Culture, Leadership, and Organizations: The GLOBE Study of 62 Societies, Sage Publications, Thousand Oaks, CA.

Hui, C.H., Yee, C. and Eastman, K.L. (1995) 'The relationship between individualism-collectivism and job satisfaction', Applied Psychology: An International Review, Vol. 44, pp.276-282.

Inkson, J.H.K. (1997) 'The man on the disassembly line: New Zealand freezing workers', Australian and New Zealand Journal of Sociology, Vol. 13, pp.1-11.

Johnson, J.J. and McIntye, C.L. (1998) 'Organizational culture and climate correlates of job satisfaction', Psychological Reports, Vol. 82, No. 3, pp.843-850.

Kaihla, P. (2003) 'The coming job boom', Business 2.0, September, available at http://www.business1.com/subscribers/articles/mag/print/0,1643,51816,00 (accessed on September 2003).

Kanter, R.M. (1972) Commitment and Community, Harvard University Press, Cambridge, MA.

Kanungo, R.N. and Wright, R.W. (1983) 'A cross-cultural comparative study of managerial job attitudes', Journal of International Business Studies, Vol. 14, pp.111-129.

Katz, R.L. and Katz, D. (1978) The Social Psychology of Organizations, p.838, Wiley, New York.

Kerr, J. and Slocum, J.W. (1987) 'Managing corporate culture through reward systems', Academy of Management Executive, Vol. 1, No. 2, pp.99-108.

Kirkman, B.L. and Shapiro, D.L. (2001) 'The impact of cultural values on job satisfaction and organizational commitment in self-managing work teams: the mediating role of employee resistance', Academy of Management Journal, Vol. 44, No. 3, p.557.

Kluckhohn, C. (1951) 'The study of culture', in Lerner, D. and Lasswell, H. (Eds.): The Policy Sciences, pp.86-101, Stanford University Press, Stanford, CA.

Kopelman, R.E., Brief, A.P. and Guzzo, R.A. (1990) 'The role of climate and culture in productivity', in Schneider, B. (Ed.): Organizational Climate and Culture, pp.282-318, Jossey-Bass, San Francisco.

Koslowsky, M., Caspy, T. and Lazar, M. (1988) 'Are volunteers more committed than nonvolunteers?', Journal of Applied Social Psychology, Vol. 18, pp.985-991.

Kristof, A.L. (1996) 'Person-organization fit: an integrative review of its conceptualizations, measurement, and implications', Personnel Psychology, Vol. 49, pp.1-49. 
Kroeber, A. and Parsons, T. (1958) 'The concepts of culture and of social system', American Sociological Review, Vol. 23, No. 5, pp.582-583.

Lahiry, S. (1994) 'Building commitment through organizational culture', Training \& Development, Vol. 48, No. 4, pp.50-53.

Lee, T.W., Mitchell, T.R., Holtom, B.C., McDaniel, L.S. and Hill, J.W. (1999) 'The unfolding model of voluntary turnover: a replication and extension', Academy of Management Journal, Vol. 42, No. 4, pp.450-462.

Lincoln, J.R. and Kalleberg, A.L. (1985) 'Work organization and workforce commitment: a study of plants and employees in the U.S. and Japan', American Sociological Review, Vol. 50, pp.738-760.

Luthans, F., McCaul, H.S. and Dodd, N.G. (1985) 'Organizational commitment: a comparison of American, Japanese, and Korean employees', Academy of Management Journal, Vol. 28, pp.213-219.

Marsh, R.M. and Mannari, H. (1977) 'Organizational commitment and turnover: a prediction study’, Administrative Science Quarterly, Vol. 22, pp.57-75.

Mathieu, J.E. and Zajac, D.M. (1990) 'A review and meta-analysis of the antecedents, correlates, and consequences of organizational commitment', Psychological Bulletin, Vol. 108, pp.171-194.

McDonald, P. (1993) 'Individual-organizational value congruence: operationalization and consequents', Unpublished doctoral dissertation, University of Western Ontario, London, ON, Canada.

Meyer, J.P. and Allen, N.J. (1991) 'A three component conceptualization of organizational commitment', Human Resource Management Review, Vol. 1, pp.61-89.

Meyer, J.P., Allen, N.J. and Smith, C.A. (1993) 'Commitment to organizations and occupations: extension and test of a three-component conceptualization', Journal of Applied Psychology, Vol. 78, pp.538-551.

Meyer, J.P., Paunonen, S.V., Gaellatly, I.R., Goffin, R.D. and Jackson, D.N. (1989) 'Organization commitment and job performance: it's the nature of the commitment that counts', Journal of Applied Psychology, Vol. 74, pp.152-156.

Mobley, W.H., Griffeth, R.W., Hand, H.H. and Meglino, B.M. (1979) 'Review and conceptual analysis of the employee turnover process', Psychological Bulletin, Vol. 86, pp.493-522.

Moon, M.J. (2000) 'Organizational commitment revisited in new public management: motivation, organizational culture, sector, and managerial level', Public Performance \& Management Review, Vol. 24, No. 2, pp.177-194.

Morrow, P. (1983) 'Concept redundancy in organizational research: the case of work commitment', Academy of Management Review, Vol. 8, pp.486-500.

Mowday, R.T., Porter, L. and Steers, R.M. (1982) Organizational Linkages: The Psychology of Commitment, Absenteeism, and Turnover, Academic Press, New York.

Near, J.P. (1989) 'Organizational commitment among Japanese and U.S. workers', Organizational Studies, Vol. 10, pp.281-300.

Netemeyer, R.G., Burton, S. and Johnston, M.W. (1995) 'A nested comparison of four models of the consequences of role perception variables', Organizational Behavior and Human Decision Processes, Vol. 61, pp.77-93.

O'Reilly, C. and Caldwell, D. (1980) 'Job choice: the impact of intrinsic and extrinsic factors on subsequent satisfaction and commitment', Journal of Applied Psychology, Vol. 65, pp.559-565.

O'Reilly, C. and Chatman, J. (1986) 'Organizational commitment and psychological attachment: the effects of compliance, identification, and internalization on prosocial behavior', Journal of Applied Psychology, Vol. 71, No. 3, pp.492-499.

O'Reilly, C., Chatman, J. and Caldwell, D. (1991) 'People and organizational culture: a profile comparison approach to assessing person-organization fit', Academy of Management Journal, Vol. 34, No. 3, pp.487-516. 
Odom, R.Y., Boxx, W.R. and Dunn, M.G. (1990) 'Organizational cultures, commitment, satisfaction, and cohesion', Public Productivity \& Management Review, Vol. 14, No. 2, pp.157-170.

Ogbonna, E. and Harris, L.C. (2000) 'Leadership style, organizational culture and performance: empirical evidence from UK companies', International Journal of Human Resource Management, Vol. 11, No. 4, pp.766-788.

Organ, D.W. (1988) Organizational Citizenship Behavior, Lexington Books, Lexington, MA.

Organ, D.W. and Konovsky, M. (1989) 'Cognitive versus affective determinants of organizational citizenship behavior', Journal of Applied Psychology, Vol. 74, pp.157-164.

Palich, L.E., Hom, P.W. and Griffeth, R.W. (1995) 'Managing in the international context: testing the cultural generality of sources of commitment to multinational enterprises', Journal of Management, Vol. 21, pp.671-690.

Perry, J. and Porter, L. (1982) 'Factors affecting the context for motivation in public organizations', Academy of Management Review, Vol. 7, pp.89-98.

Pool, S.W. (2000) 'Organizational culture and its relationship between job tension in measuring outcomes among business executives', Journal of Management Development, Vol. 19, No. 1, pp.32-48.

Porter, L., Steers, R., Mowday, M. and Boulin, R. (1974) 'Organizational commitment, job satisfaction, and turnover among psychiatric technicians', Journal of Applied Psychology, Vol. 54, pp.603-609.

Randall, D.M. (1993) 'Cross-cultural research on organizational commitment: a review and application of Hofstede's value survey module', Journal of Business Research, Vol. 26, pp.91-110.

Robie, C., Ryan, A.M., Schmieder, R.A., Parra, L.F. and Smith, P.C. (1998) 'The relations between job level and job satisfaction', Group and Organization Management, Vol. 23, pp.470-495.

Ronen, S. and Shenkar, O. (1985) 'Clustering countries on attitudinal dimensions: a review and synthesis', Academy of Management Review, Vol. 10, pp.435-454.

Scarpello, V. and Campbell, J.P. (1983) 'Job satisfaction: are all the parts there?', Personnel Psychology, Vol. 36, pp.577-600.

Schein, E. (1983) 'The role of the founder in creating organizational culture', Organizational Dynamics, Summer, pp.13-28.

Schein, E. (1996) 'Leadership and organizational culture', in Hesselbein, F., Goldsmith, M. and Bechard, R. (Eds.): The Leader of the Future, pp.61-62, Jossey-Bass, San Francisco.

Schmit, M.J. and Allscheid, S.P. (1995) 'Employee attitudes and customer satisfaction: making theoretical and empirical connections', Personnel Psychology, Vol. 48, pp.521-536.

Schneider, B. (1987) 'The people make the place', Personnel Psychology, Vol. 40, pp.437-453.

Schneider, S. (1988) 'National vs. corporate culture: Implications for human resource management', Human Resource Management, Summer, p.239.

Sheridan, J. (1992) 'Organizational culture and employee retention', Academy of Management Journal, Vol. 35, No. 5, pp.1036-1056.

Sommer, S.M., Bae, S. and Luthans, F. (1996) 'Organizational commitment across cultures: the impact of antecedents on Korean employees', Human Relations, Vol. 49, pp.977-993.

Staw, B. (1977) 'Two sides of commitment', Paper presented at the Annual Meeting of Academy of Management, August, Orlando, FL.

Taras, V. and Steel, P. (2008) 'Challenging fundamental assumptions about culture: a multi-level multivariate meta-analysis', in C. Nakata (Ed.): Beyond Hofstede: Culture Frameworks for Global Marketing and Management, Macmillan/Palgrave.

Tepeci, M. and Bartlett, A.L.B. (2002) The hospitality industry culture profile: a measure of individual values, organizational culture, and person-organization fit as predictors of job satisfaction and behavioral intentions', International Journal of Hospitality Management, Vol. 21, No. 2, pp.151-170. 
Terborg, J. (1981) 'International psychology and research on human behavior in organizations', Academy of Management Review, Vol. 6, pp.569-576.

Tett, R.P. and Meyer, J.P. (1993) 'Job satisfaction, organizational commitment, turnover intention, and turnover: path analyses based on meta-analytical findings', Personnel Psychology, Vol. 46, pp.259-293.

Triandis, H. (1972) The Analysis of Subjective Culture, Wiley, New York.

Trompenaars, F. (1993) Riding the Waves of Culture, Nicholas Brealey, London.

Tzeng, H., Ketefian, S. and Redman, R.W. (2002) 'The relationship of nurses' assessment of organizational culture, job satisfaction and patient satisfaction with nursing care', International Journal of Nursing Studies, Vol. 39, No. 1, pp.79-84.

van Vianen, A.E.M. (2000) 'Person-organization fit: the match between newcomers' and recruiters' preferences for organizational cultures', Personnel Psychology, Vol. 53, No. 1, pp.113-149.

Vandenberghe, C. (1999) 'Organizational culture, person-culture fit, and turnover: a replication in the health care', Journal of Organizational Behavior, Vol. 20, No. 2, pp.175-184.

Verkuyten, M., de Jong, W. and Masson, C.N. (1993) 'Job satisfaction among ethnic minorities in the Netherlands', Applied Psychology: An International Review, Vol. 42, pp.171-189.

Wanous, J.P., Reichers, A.E. and Hudy, M. (1997) 'Overall job satisfaction: how good are single-item measures?', Journal of Applied Psychology, Vol. 82, pp.247-252.

Whitener, E.M. and Walz, P.M. (1993) 'Exchange theory determinants of affective and continuance commitment and turnover', Journal of Vocational Behavior, Vol. 42, pp.265-281.

Zuboff, S. (2004) 'Evolving from subject to citizen', Fast Company, May, Vol. 82, p.104. 